\title{
DOI 10.26886/2414-634X.5(24)2018.3
}

UDC: 001.8:330.342 (477)

THE EVALUATION OF SCIENTIFIC POTENTIAL OF THE DOMESTIC ECONOMIC SYSTEM

\section{Svidruk, PhD in Economical Sciences}

Lviv Trade and Economic University, Ukraine, Lviv

\section{Myronova, PhD in Economical Sciences}

Average general educational school number 90, Ukraine, Lviv

The national scientific potential as a source of effective cooperation of business and science is researched. The dynamics of conducting scientific activity by the subjects of the national economy testifies to a certain fate of the national scientific tradition. There are tendencies in the reduction of scientific and technical knowledge and the increase in the number of scientific personnel, mostly in the public sector of the economy. The problem of domestic science is the high level of "outflow of intelligence", mainly in the fields of biology, physics and mathematics. So, there is a need to update the organizational management of scientific activity. The low position of Ukraine in the world rankings of the knowledge economy testifies to system gaps in cooperation between science and business. At the same time, the existing potential opens the prospect of integration with the European Research Area, provided that it approaches the EU policy in the relevant area.

Key words: knowledge economy, fundamental and applied science, scientific personnel, scientific activity, intelligence, research space.

кандидат экономических наук, Свидрук I. I., кандидат економічних наук, Миронова М. І. Оцінка наукового потенціалу вітчизняної економічної системи / Львівський торговельноекономічний університет, Україна, Львів; середня загальноосвітня 
школа № 90, Україна, Львів

Досліджено вітчизняний науковий потенціал як джерело ефрективної співпраці бізнесу і науки. Динаміка провадження наукової діяльності суб'єктами вітчизняної економіки свідчить про певну усталеність національної наукової традиції. Спостерігаються тенденції скорочення науково-технічного та збільшення кількості наукового персоналу, здебільшого в державному секторі економіки. Проблемою вітчизняної науки є високий рівень «відпливу інтелекту», переважно у галузях біології, фрізики та математики. Отож, існує необхідність оновлення організаційного управління науковою діяльністю. Низькі позиції України у світових рейтингах знаннєвої економіки свідчать про системні прогалини у співпраці науки і бізнесу. Водночас наявний потенціал відкриває перспективи інтеграції 3 Європейським дослідницьким простором за умови наближення до політики ЄС у відповідній сфрері.

Ключові слова: знаннєва економіка, фрундаментальна і прикладна наука, наукові кадри, наукова діяльність, інтелект, дослідницький простір.

Вступ. Стратегічні пріоритети розвитку вітчизняної економічної системи, орієнтовані на високотехнологічний «прорив», вимагають активного розвитку національної знаннєвої економіки, а отже, актуалізують питання підвищення ефективності фундаментальної та прикладної вітчизняної науки. Дослідженню окремих аспектів постіндустріалізаційних трансформацій економічних систем присвячено чимало наукових робіт сучасних економістів, однак, здебільшого вони мають фрагментарний характер і висвітлюють лише вузькоспеціалізовані аспекти. Так, слід відмітити вагомий внесок Ю. Бажала, Л. Федулової, Л.Височіної, О. Шнипко у вивчення теоретичних 
аспектів інституційного впливу на розвиток економіки знань, дослідження А. Сингаївської, Т. Ткаченко, І. Ханіна, присвячені діяльності наукового сектору економіки, роботи Л. Безчасного, С. Харабуги, О. Яременко у галузі соціально-економічної організації наукового простору та ін. Натомість дотепер залишається нерозробленою системна концепція дослідження місця, ролі і значення фунда-ментальної і прикладної науки у трансформаційних перетвореннях, що вимагає детального розгляду та критеріальної оцінки всіх аспектів її функціонування.

Мета та завдання. Метою дослідження $\epsilon$ аналіз потенціалу наукового сектору вітчизняної економіки для забезпечення гармонійного зростання знаннєвої економіки.

Виклад основного матеріалу. На етапі постіндустріалізаційних трансформацій креативний розвиток економічних систем вже не $\epsilon$ лише стратегічним вибором, він добирає рис нагальної необхідності та чи не єдиної передумови забезпечення економічного зростання держави. В репрезентованому в вересні 2010 р. докладі Генерального секретаря Європейської комісії «Європа 2020 - Стратегія інтелектуального, сталого і всеосяжного розвитку» особливо наголошується, що розвиток наукового сектору економіки $\epsilon$ пріоритетним напрямом гармонійного економічного зростання на основі знань, креативних ідей та інновацій, вимагаючи додаткової інституційної підтримки щодо підвищення якості освіти, провадження наукових досліджень, інноваційних перетворень та використання інформаційних та комунікаційних технологій [1]. Іншими пріоритетами гармонійного економічного оновлення $\epsilon$ сталий розвиток, тобто сприяння розвитку ресурсозберігаючої, екологічно чистої конкурентоспроможної економіки та інклюзивне зростання стимулювання економіки високої зайнятості, що забезпечує соціальний 
та територіальний рівень згуртованості суспільства.

Акцентування національних стратегічних пріоритетів на розвитку знаннєвої економіки гостро піднімає питання підвищення ефективності фрундаментальної та прикладної вітчизняної науки, що вимагає детального розгляду та критеріальної оцінки всіх аспектів ії фрункціонування [2]. Зокрема, чинним Порядком оцінки розвитку діяльності наукової установи [3] передбачено таку систему показників оцінювання (самооцінювання) наукового потенціалу, результативності і перспектив діяльності наукової установи:

1. Рівень цільової орієнтації досліджень: відповідність тематики наукових робіт пріоритетним напрямам розвитку науки і техніки; відповідність тематики наукових робіт завданням за державним замовленням.

2. Оцінка результатів наукової (науково-технічної) діяльності: рівень використання потенціалу для виконання робіт; найбільш вагомі результати фундаментальних досліджень, отриманих за попередні п'ять років; найбільш вагомі результати прикладних досліджень і науково-технічних розробок, отриманих за попередні п'ять років.

3. Оцінка перспектив розвитку науково-технічної діяльності: суспільна потреба в результатах досліджень і розробок; важливість профрілю діяльності установи (від ординарної до унікальної); забезпечення кадровими, фрінансовими та матеріально-технічними ресурсами, необхідними для утримання наукової установи та розвитку досліджень; інноваційні перспективи діяльності на наступні два роки; рівень найбільш значних досліджень і розробок, що передбачається завершити у наступні два роки [3].

Динаміку провадження наукової діяльності суб'єктами вітчизняної економічної системи та її секторальний розподіл представлено в табл. 1. 
Таблиця 1

Динаміка та секторальний розподіл організацій, що здійснювали наукові дослідження і розробки (НДР) в Україні у 2013-2017 рр. (за даними [4])

\begin{tabular}{|l|c|c|c|c|c|c|c|}
\hline \multicolumn{1}{|c|}{ Показники } & 2013 & 2014 & 2015 & 2016 & 2017 & $\begin{array}{c}2017 / \\
2016, \\
\%\end{array}$ & $\begin{array}{c}2017 / \\
2013, \\
\%\end{array}$ \\
\hline $\begin{array}{l}\text { Кількість організацій, що } \\
\text { виконували НДР, од. }\end{array}$ & 1143 & 999 & 984 & 972 & 963 & 99,1 & 84,3 \\
\hline $\begin{array}{l}\text { у т.ч.: - державний сектор } \\
\text { економіки, \% }\end{array}$ & 44,4 & 42,0 & 45,5 & 46,6 & 45,8 & 98,3 & 103,2 \\
\hline $\begin{array}{l}\text { - підприємницький сектор } \\
\text { економіки, \% }\end{array}$ & 39,9 & 42,2 & 38,8 & 37,7 & 39,0 & 103,4 & 97,7 \\
\hline - заклади вищої освіти, \% & 15,7 & 15,8 & 15,7 & 15,7 & 15,2 & 96,8 & 96,8 \\
\hline
\end{tabular}

* Тут і в подальшому - без урахування тимчасово окупованої території Автономної Республіки Крим, м. Севастополя та частини зони проведення антитерористичної операції

Як бачимо, попри рівномірність секторального розподілу за роками, спостерігається стабільна тенденція до незначного скорочення кількості організацій, що проваджували наукову та дослідницьку діяльність. Щодо їх підпорядкування, то слід відмітити, що у 2017 р. у Національній академії наук України було задіяно 181 наукову організацію (у 2013 р. - 196 організацій), у Міністерстві освіти і науки України - 119, у Національній академії аграрних наук України - 86, у Міністерстві аграрної політики та продовольства України - 51, у Міністерстві охорони здоров'я України та у Національній академії медичних наук по 35, у Міністерстві економічного розвитку і торгівлі України - 34, у Національній академії педагогічних наук - 12 організацій (у 2013 р. - 16 наукових організацій). 


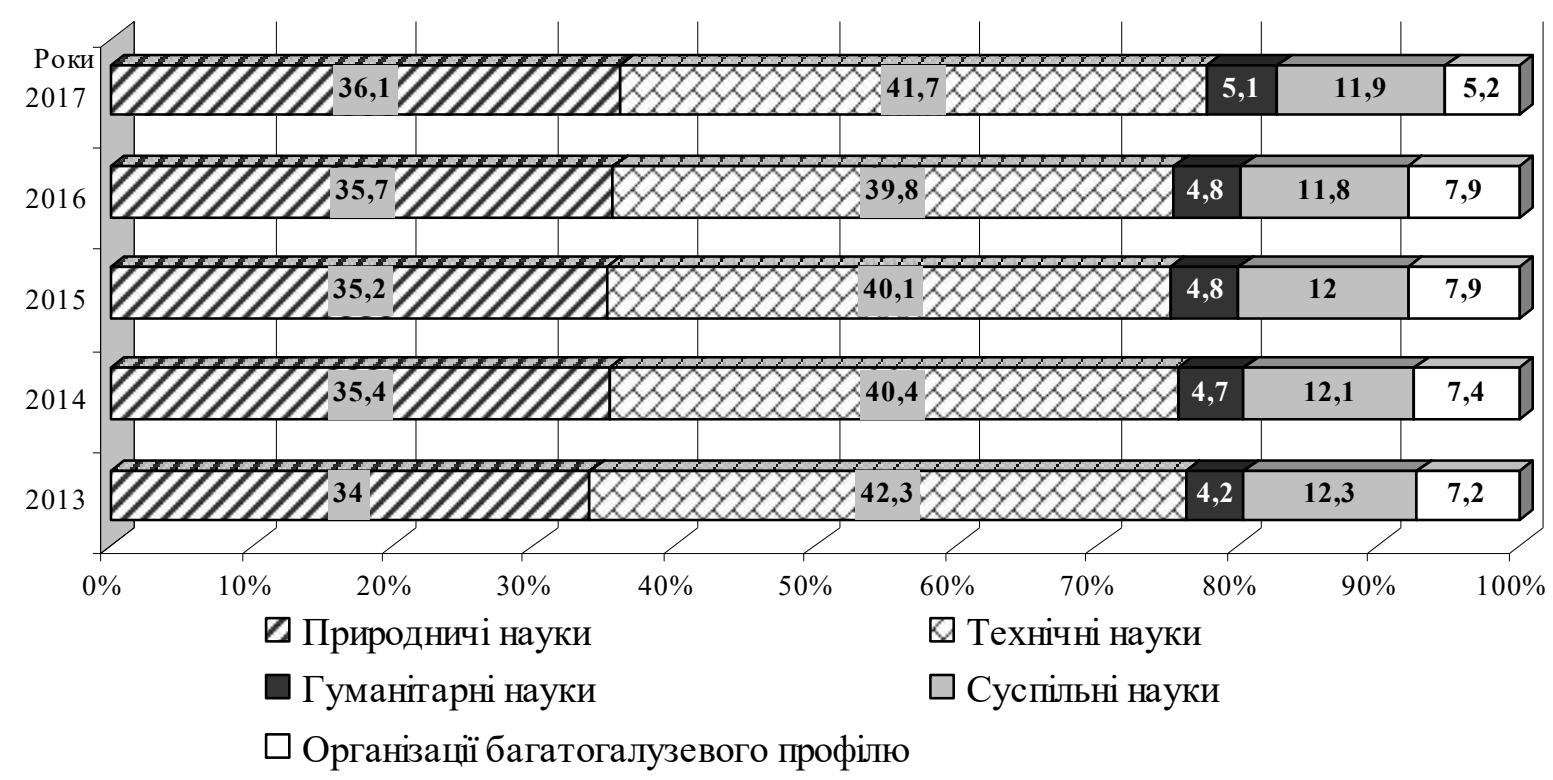

Рис. 1. Динаміка розподілу організацій, які виконували НДР у 2013-2017 рр. за галузями наук, \% (за даними [4] )

Водночас, галузевий розподіл наукових організацій за роками залишався доволі однорідним (рис. 1), що свідчить про певну усталеність національної наукової традиції.

Спостерігається лише незначне збільшення частки наукових організацій, що провадять дослідження у сферах природничих та гуманітарних наук, що компенсується ії зменшенням в організаціях багатогалузевого профрілю [5].

Аналіз територіального розподілу наукового потенціалу свідчить, що понад $30 \%$ організацій, що провадили наукові дослідження i розробки, функціонують у м. Києві, 16,5\% розташовані у Харківській області, $7,5 \%$ - у Львівській області, 6\% наукових організацій знаходяться у Дніпропетровській та маже 5\% - в Одеській областях.

Зокрема, у Києві розташована Національна академія наук України, до складу якої входить 168 наукових установ. Креативний розвиток столиці репрезентують численні коворкінги та арт-простори, освітянські та наукові форуми і наукові конференції. Так, у березі 2017 р. розпочав роботу найбільший в Україні креативний офрісний простір 
для It-фрахівців і стартапів Creative Quarter, концепція якого ґрунтується на принципах економіки спільного споживання: резидентам надають послуги бек-офрісу, ком'юніті-менеджерів, забезпечують тренінги матеріально-технічною підтримкою тощо. У липні 2017 р. під час зустрічі Президента України П.О. Порошенка із науково-педагогічним складом Київського політехнічного інституту ім. Ігоря Сікорського було оприлюднено інформацію про наукові здобутки колективу закладу щодо створення і впровадження інноваційних розробок в оборонному секторі, зокрема безпілотних авіаційних комплексів та навколоземних космічних наносупутників.

Харків є одним з найефективніших креативних центрів України, в якому до науково-дослідницької діяльності у 2017 р. було залучено понад 16 тис. фрахівців, з них 4,6 тис. науковців із вченим ступенем доктора чи кандидата наук. Історично склалося, що в Харкові працювали вчені зі світовими іменами у галузях фрізики (серед найвідоміших - Л. Ландау, К. Синельников, А. Іофрфе), хімії (М. Бекетов, О. Палладін), біології (І. Мечников), математики (І. Ахієзер, М. Остроградський), астрономії (М. Барабашов), започатковувались наукові школи різного спрямування. Саме харківськими вченимифрізиками вперше в Європі було здійснено вдалий дослід 3 розщеплення атому, розроблено найсучасніший радіотелескоп та установки радіолокаційного зондування атмосфрери, винайдено прискорювач елементарних часточок і запропоновано спосіб вирощування монокристалів [6]. Серед найвагоміших креативних здобутків харківських науковців також слід відмітити створення першої в Україні лабораторії репродукції людини та позитивний досвід першого в Україні вдалого запліднення in vitro.

У Львові, який відомий численними бізнес-інкубаторами і технопарками, за сприяння міської ради започатковано програму 
«Львів науковий. 2017-2018 роки», в рамках якої проводиться конкурс соціально-наукових проектів. У березні 2018 р. під час форуму «Креативний прорив» було репрезентовано нову стратегію креативного розвитку міста, в основу якої покладено принципи партисипативності та партнерського підходу до реалізації. Означені у стратегії три основні напрямки соціального характеру передбачають програми виховання креативності в місті, утримання креативних мешканців та створення умов для повернення креативних людей з трудової еміграції.

Попри наявність вагомих здобутків вітчизняної науки, занепокоєння викликає фракт неухильного скорочення науковотехнічного персоналу, тенденції якого залишаються незмінними впродовж 2013-2017 р. (табл. 2).

Таблиця 2

Категоріальний розподіл персоналу наукових організацій в Україні у 2013-2017 рр. (за даними [4])

\begin{tabular}{|c|c|c|c|c|c|c|c|}
\hline Показники & 2013 & 2014 & 2015 & 2016 & 2017 & $\begin{array}{c}2017 / \\
2016, \\
\%\end{array}$ & $\begin{array}{c}2017 / \\
2013, \\
\%\end{array}$ \\
\hline $\begin{array}{l}\text { Усього наукового персоналу, } \\
\text { тис. ос. }\end{array}$ & 123,2 & 109,6 & 122,5 & 97,9 & 94,3 & 96,3 & 76,5 \\
\hline У т.ч.: - дослідники, тис. ос. & 65,6 & 58,7 & 90,2 & 63,7 & 59,4 & 93,2 & 90,5 \\
\hline у \% до загальної кількості & 53,3 & 53,5 & 73,6 & 65,1 & 63,0 & $\mathrm{X}$ & $\mathrm{X}$ \\
\hline - техніки & 12,2 & 10,7 & 11,2 & 10 & 9,1 & 91,0 & 74,6 \\
\hline у \% до загальної кількості & 9,9 & 9,8 & 9,1 & 10,2 & 9,7 & $\mathrm{X}$ & $\mathrm{X}$ \\
\hline - допоміжний персонал & 22,6 & 20,2 & 21,1 & 24,2 & 25,7 & 106,2 & 113,7 \\
\hline у \% до загальної кількості & 18,4 & 18,4 & 17,2 & 24,7 & 27,3 & $\mathrm{X}$ & $\bar{X}$ \\
\hline \multicolumn{8}{|l|}{3 них мають науковий ступінь: } \\
\hline - доктора наук, тис. ос. & 4,5 & 4,2 & 9,6 & 7,1 & 6,9 & 97,2 & 153,3 \\
\hline у \% до загальної кількості & 3,7 & 3,9 & 7,8 & 7,3 & 7,3 & $\mathrm{X}$ & $\mathrm{X}$ \\
\hline - кандидата наук, тис. ос. & 15,9 & 14,8 & 32,8 & 20,2 & 19,2 & 95,0 & 120,8 \\
\hline у \% до загальної кількості & 12,9 & 13,5 & 26,8 & 20,6 & 20,4 & $\mathrm{X}$ & $\mathrm{X}$ \\
\hline
\end{tabular}


Так, за цей період загальне скорочення кількості наукових працівників склало 23,5\% (майже на 20 тис. осіб), у т.ч. кількість дослідників скоротилась на 9,5\% (на 6,2 тис. осіб), спостерігається стрімке зменшення кількості технічного персоналу (на 25,4\% або на 3,1 тис. осіб). Разом з тим, у наукових організаціях збільшилась кількість допоміжного персоналу на 13,7\% (на 3,1 тис. осіб).

Нестабільна динаміка за роками із тенденцією до загального збільшення спостерігається за показником наявності наукового ступеня у персоналу наукових організацій. Частка докторів і кандидатів наук серед всіх виконавців НДР становила у 2017 р. 27,7\%, у т.ч. серед дослідників - 43,8\%. Більшість з них працювали в державному секторі економіки, 36,1\% - у галузі вищої освіти, 5,4\% - у підприємницькому секторі.

Аналізуючи відповідні показники за 2013-2017 рр. можна стверджувати про певний «прорив» вітчизняної науки, адже за цей період кількість докторів наук збільшилась у понад півтора рази, а кандидатів наук - більше як на 20\%. Водночас, найкращими ці показники були у 2015 р., коли відбулося їх стрімке зростання, а у подальшому спостерігається стійка негативна тенденція.

Зауважимо, що в листопаді 2017 р. на розширеному засіданні Комітету Верховної Ради України з питань науки і освіти Міністр освіти і науки України Л. М. Гриневич оприлюднила інформацію про тенденції втрати кращих вітчизняних науковців та тлі глобального розвитку науки у світі [7]. За результатами проведеного МОН України соціологічного опитування, понад $64 \%$ опитаних науковців стверджують про погіршення стану вітчизняної науки, а майже третина вчених готові до трудової еміграції. Все це спричинило один з найбільших у світі рівень «відпливу інтелекту», переважно в середовищі науковців у галузі біології, фрізики та математики, які масово виїжджають в наукові 
установи інших країн або взагалі припиняють наукову діяльність і переорієнтовуються на інші сегменти національного економічного господарства. Отож, нагально визріла необхідність докорінної зміни організаційного управління науковою діяльністю, зокрема запровадження структурованих докторських програм і шкіл, зміни компетентнісної моделі науковців, збільшення кар'єрних можливостей тощо.

У загальній кількості економічно зайнятого населення частка виконавців НДР, включаючи дослідників і допоміжного персоналу) у 2017 р. становила менше 1\%. Зважаючи на нагальність науковотехнологічного прориву для успішного конкурентного розвитку національної економічної системи, важливо порівняти ці дані із відповідними показниками країн, традиційно визнаними міжнародною спільнотою лідерами у галузі креативного розвитку та країн, які тільки розкривають свій науковий потенціал (рис. 2)

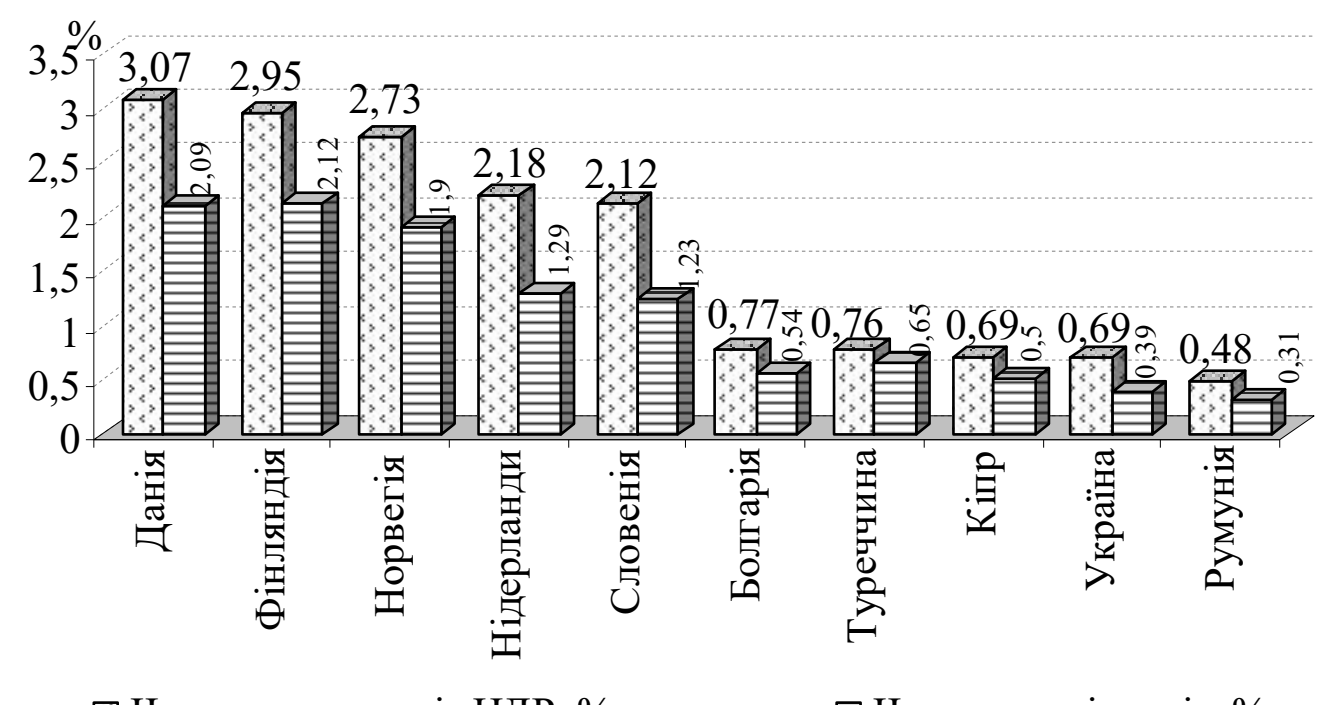

๑ Частка виконавців НДР, \% 曰 曰 Частка дослідників, \%

Рис. 2. Порівняння частки наукового персоналу серед загальної кількості економічно зайнятого населення України та деяких інших країн у 2017 р. (за даними [8])

Як бачимо, невисокі позиції України у світовому рейтингу свідчать 
про нереалізований потенціал вітчизняної науки, недостатність кількості науковців у виробничому секторі національної економічної системи, системні прогалини у співпраці науки і бізнесу.

Висновки. Таким чином, науковий сектор економіки покликаний забезпечувати гармонійне зростання знаннєвої економіки, однак в сучасних економічних реаліях вітчизняна наука зазнає негативного впливу низки фракторів. Водночас спрямованість національної науки у напрямку глобалізаційного науково-економічного простору відкриває нові перспективи інтеграції з Європейським дослідницьким простором, наближення вітчизняного інституційного забезпечення науки до політики ЄС у відповідній сфрері.

\section{תimepamypa:}

1. European commission. Europe 2020 - A strategy for smart, sustainable and inclusive growth COM. - [Electronic resource]. - Access mode: https://eur-lex.europa.eu/legalcontent/EN/TXT/PDF/?uri=CELEX:52010DC2020\&from=DE.

2. Попело О. В. Фундаментальні дослідження як ядро інноваційного розвитку регіонів України / О. В. Попело // Сталий розвиток економіки. - 2015. - №3 (28). - С. 153-160.

3. Про затвердження Порядку оцінки розвитку діяльності наукової установи. Наказ МОНмолодьспорт України від 03.04.2012 № 399 // Офріційний вісник України від 21.05.2012. - 2012. - № 36. - С. 312, cm. 1356, код акта 61509/2012.

4. Наука, технології та інновації / Державна служба статистики. Статистична інформація. Економічна статистика. - [Електронний ресурс]. - Режим доступу: http://www.ukrstat.gov.ua/.

5. Стан розвитку науки і техніки, результати наукової і науковотехнічної діяльності за 2017 рік. Аналітична довідка. - Київ: 
Український інститут науково-технічної експертизи та інформації МОН України, 2018. - 92 с.

6. Про внутрішне та зовнішне становище України в 2017 році. Аналітична доповідь до Щорічного Послання Президента України до Верховної Ради України. - Київ: НІСД, 2017. - 928 с.

7. Про стан реалізації Закону України «Про наукову і науково-технічну діяльність». Розширене засідання Комітету Верховної Ради України з питань науки і освіти 15.11.2017. - [Електронний ресурс]. - Режим доступу:

http://kno.rada.gov.ua/documents/zasid/75091.html.

8. Statistical reports Product Labour Force Survey in the EU, candidate and EFTA countries - Main characteristics of national surveys 2017 / European Commission. Eurostat Products. - [Electronic resource]. - Access mode: http://ec.europa.eu/ eurostat/web/products-statistical-reports/-/KS-TF-18002? inheritRedirect=true\&red irect=\%2Feurostat\%2Fpublications\%2Fstatistical-reports.

\section{References:}

1. European commission. Europe 2020 - A strategy for smart, sustainable and inclusive growth COM. - [Electronic resource]. - Access mode: https://eur-lex.europa.eu/legal-

content/EN/TXT/PDF/?uri=CELEX:52010DC2020\&from=DE.

2. Popelo O. V. Fundamentalni doslidzhennia yak yadro innovatsiinoho rozvytku rehioniv Ukrainy / O. V. Popelo // Stalyi rozvytok ekonomiky. 2015. - №3 (28). - S. 153-160.

3. Pro zatverdzhennia Poriadku otsinky rozvytku diialnosti naukovoi ustanovy. Nakaz MONmolodsport Ukrainy vid 03.04.2012 № 399 // Ofitsiinyi visnyk Ukrainy vid 21.05.2012. - 2012. - № 36. - S. 312, st. 1356, kod akta 61509/2012.

4. Nauka, tekhnolohii ta innovatsii / Derzhavna sluzhba statystyky. 
Statystychna informatsiia. Ekonomichna statystyka. - [Elektronnyi resurs]. Rezhym dostupu: http://www.ukrstat.gov.ua/.

5. Stan rozvytku nauky i tekhniky, rezultaty naukovoi i naukovo-tekhnichnoi diialnosti za 2017 rik. Analitychna dovidka. - Kyiv: Ukrainskyi instytut naukovo-tekhnichnoi ekspertyzy ta informatsii MON Ukrainy, 2018. - 92 s.

6. Pro vnutrishnie ta zovnishnie stanovyshche Ukrainy $v 2017$ rotsi. Analitychna dopovid do Shchorichnoho Poslannia Prezydenta Ukrainy do Verkhovnoi Rady Ukrainy. - Kyiv: NISD, 2017. - 928 s.

7. Pro stan realizatsii Zakonu Ukrainy «Pro naukovu i naukovo-tekhnichnu diialnist». Rozshyrene zasidannia Komitetu Verkhovnoi Rady Ukrainy z pytan nauky i osvity 15.11.2017. - [Elektronnyi resurs]. - Rezhym dostupu: http://kno.rada.gov.ua /documents/zasid/75091.html.

8. Statistical reports Product Labour Force Survey in the EU, candidate and EFTA countries - Main characteristics of national surveys 2017 / European Commission. Eurostat Products. - [Electronic resource]. - Access mode: http://ec.europa.eu/ eurostat/web/products-statistical-reports/-/KS-TF-18002?inheritRedirect=true\&red irect=\%2Feurostat\%2Fpublications\%2Fstatistical-reports. 